\title{
Powdery Mildew Control and Yield Response of Inodorus Melon
}

\author{
Ippolito Camele ${ }^{* 1}$, Gabriele Campanelli², Valentino Ferrari ${ }^{2}$, Giovanni Viggiani ${ }^{3}$, \\ Vincenzo Candido 3 \\ ${ }^{1}$ Università della Basilicata, Dipartimento di Biologia, Difesa e Biotecnologie Agro-Forestali, \\ Viale dell'Ateneo Lucano 10, 85100 Potenza, Italy \\ ${ }^{2}$ Consiglio per la Ricerca e la Sperimentazione in Agricoltura, Istituto Sperimentale per l'Orticoltura, \\ sezione di Monsampolo del Tronto, Via Salaria 1, 43030 Monsampolo (AP), Italy \\ ${ }^{3}$ Università della Basilicata, Dipartimento di Scienze dei Sistemi Colturali, Forestali e dell'Ambiente, \\ Viale dell'Ateneo Lucano 10, 85100 Potenza, Italy
}

Received: 14 February 2009. Accepted: 29 May 2009.

\begin{abstract}
The research was carried out on melon (Cucumis melo L. var. inodorus Naud.) in 2006 and 2007 at "Pantanello" Experimental Farm ( $40^{\circ} 24^{\prime} \mathrm{N}$; $16^{\circ} 48^{\prime} \mathrm{E}$; $10 \mathrm{~m}$ a.s.l.; Metaponto, southern Italy) to evaluate the efficacy of a low environmental impact control strategy against powdery mildew of cucurbits.

Winter melon was treated with a new anti-oidium formulation, called Stifénia, obtained from fenugreek seeds and stimulating the plant self-defence. The adopted experimental design included two control strategies (1. biological, using Stifénia and 2. conventional, using penconazole, myclobutanil and sulphur) and an untreated control (treated with water alone) applied to two cultivars of inodorus melon (cv 'Amarillo' and $\mathrm{HF}_{1}$ 'Cocorito', the latter a genotype resistant to powdery mildew). Stifénia applications were not effective against the disease; in fact, there were no differences in percentage of attacked plant surface between treated plots and untreated ones. The melon marketable yield was significantly higher with the conventional strategy respect to Stifénia and control. Repeated applications of Stifénia resulted in a significant decrease of marketable yield even in comparison with the untreated control. The cultivars significantly affected powdery mildew development, since the resistant one ('Cocorito') was attacked later and damaged always lower than the non-resistant genotype ('Amarillo'). Laboratory analyses carried out on infected leaves always confirmed that Golovinomyces cichoracearum D.C. was responsible of the disease.
\end{abstract}

Key-words: Cucumis melo L., PCR, Golovinomyces cichoracearum, fruit quality.

\section{Introduction}

Melon (Cucumis melo L.) is an important vegetable crop in Italy, cultivated in 22,450 ha in the open field and 3,497 ha in greenhouses for a total production of 616,664 t (Istat 2007). Only $C$. melo var. reticulatus Naud. and var. cantalupensis Naud. are present in central-northern Italy; in the south, open field cultivation occurs exclusively with the inodorus cultivars while the reticulatus and cantalupensis types are grown mostly in greenhouses (Incalcaterra and Vetrano, 2007).

Powdery mildew, a very common disease of melon, almost always requires specific chemical treatments for its control; although non-destructive, it can cause serious damages both in open field and in protected cultivation (Brunelli, 2007). The main its aetiological agents are Golovinomyces cichoracearum D.C. V.P. Heluta (syn. Erysiphe cichoracearum D.C.) and Podosphaera xanthii (Schlechtend: Fr.) Pollacci (syn. Sphaerotheca fuliginea Schlecht), whose infections induce on melon indistinguishable symptomatologies. The two mycetes can only be recognized by microscopic observation of their respective propagative and conservative structures. In P. xanthii, conidia are cylindrical and cleistothecia contain a single ascus with 8 as-

* Corresponding Author: Tel. +39 0971 205544; Fax: +39 0971 205378. E-mail: ippolito.camele@unibas.it Authors equally shared the work. 
cospores, while in $G$. cichoracearum conidia are ellipsoid and cleistothecia contain 10-15 asci enclosing only 2-3 ascospores. G. cichoracearum is a polyphagous pathogen able to infect a large number of spontaneous and cultivated plants (Braun, 1995; Garibaldi et al., 2008). In melon, the fungus mainly affects the vegetative structures (leaves, stalks, stems), which are covered by white powder-like spots, while symptoms rarely occur on the fruits. The damage consists in lower weight-based productivity and qualitative fruit decline, i.e. loss of aroma and sugar content. Chemical defence strategies can count on a fairly large range of active substances with pre-harvest intervals varying from 3 to 14 days, which, nevertheless, can give rise to resistance phenomena. This is can occur with benzimidazoles, sterol biosynthesis inhibitors (SBI) and strobilurine analogues, for all of which cases of reduced fungicidal efficacy have been reported (McGrath and Shishkoff, 2003; Fernandez-Ortuno et al., 2006). Therefore, it would be useful to enrich the current defence strategies with formulations having innovative mechanisms of action but also a low impact on the agroecosystem and short pre-harvest intervals.

The aim of this two-year study was to assess the efficacy on winter melon of a new natural anti-oidium formulation, called Stifénia, and obtained from fenugreek seeds (Trigonella foenumgraecum L.). This product has been provisionally authorized for use on grapevine in France but it has not yet been marketed in Italy. As it has no toxic effects on mammals, insects, pollinators, fishes, birds or soil micro-organisms, it is suitable for use in organic agriculture. The formulation does not act directly on the pathogen, but when preventively used it induces plant resistance to powdery mildew due to higher endogenous production of compounds such as salicylic acid, jasmonic acid and ethylene (Clergue and Martinez, 2006).

\section{Materials and methods}

The research was carried out in open field with medium-texture soil in 2006 and 2007 at "Pantanello" Experimental Farm $\left(40^{\circ} 24^{\prime} \mathrm{N}\right.$; $16^{\circ} 48^{\prime} \mathrm{E}$; $10 \mathrm{~m}$ a.s.l.), Metaponto, Southern Italy. Each year, the soil was ploughed to a depth of $30 \mathrm{~cm}$, followed by harrowing tillage, levelling and pretransplantation fertilization with, respectively, 80,80 and $150 \mathrm{~kg} \mathrm{ha}^{-1}$ of $\mathrm{N}, \mathrm{P}_{2} \mathrm{O}_{5}$ and $\mathrm{K}_{2} \mathrm{O}$; plas- tic mulching was laid down by covering $80 \mathrm{~cm}$ wide bands of soil with black LDPE $(50 \mu \mathrm{m}$ thick). Melon seedlings, at the stage of $3^{\text {rd }}-4^{\text {th }}$ true leaf, were transplanted on May $26^{\text {th }} 2006$ and June $5^{\text {th }} 2007$, spaced at 1-m intervals in rows $2 \mathrm{~m}$ apart so as to create a density of 0.5 plants $\mathrm{m}^{-2}$. Throughout the crop cycle, watering was carried out with a drip irrigation system (2.5 $1 \mathrm{~h}^{-1}$ ) placed under the plastic mulch, with drip holes every $20 \mathrm{~cm}$. Post-transplantation fertilization involved the total supply of $40 \mathrm{~kg} \mathrm{ha}^{-1}$ of $\mathrm{N}, 70$ of $\mathrm{P}_{2} \mathrm{O}_{5}$ and 50 of $\mathrm{K}_{2} \mathrm{O}$ by fertirrigation. Phytosanitary defence was performed with chemical treatments against either phythopatogenous fungi or insects if necessary.

For the trials, we used two inodorus melon cultivars from "Seminis Italia" seed Company: 'Amarillo' and 'Cocorito $\mathrm{F}_{1}$ ', the former not resistant to powdery mildew and the latter resistant to it. All anti-oidium treatments were carried out with sprayer powered by a 2-cycle engine; spray pressure was 5-6 bar and water volume varied from 400 to $8001 \mathrm{ha}^{-1}$ according to crop development degree.

In both years, the experimental soil surface was divided into three large plots for conventional treatment ('conv') with traditional formulations, biological treatment ('bio') with Stifénia and untreated control, respectively. Each plot was divided into two $42 \mathrm{~m}^{2}$ sub-plots $(6.0 \mathrm{~m} \times 7.0 \mathrm{~m})$ for the two melon cultivars. Therefore 6 experimental treatments were totally obtained, that were arranged in a split-plot complete block design with three reps setting the anti-oidium defence strategies in the main plots and the cultivars in the sub-plots.

Plants of the 'bio' treatment plots were sprayed with Stifénia (a wettable powder formulation) 6 times in 2006 and 5 times in 2007. Treatments were spaced 8 days apart beginning from crop taking root, with a dose of $1.5 \mathrm{~kg} \mathrm{ha}^{-1}$. In the 'conv' treatment plots, plants were alternately treated, every two weeks, with systemic formulations 3 times in 2006 and 4 in 2007. The used fungicides were topas 10EC (p.a. penconazole $10.2 \%$ at a dose of $50 \mathrm{ml} \mathrm{hl}^{-1}$ ) and thiocur 12 (p.a. myclobutanil $6.2 \%$ at a dose of $40 \mathrm{ml} \mathrm{hl}^{-1}$ ); moreover, wettable sulphur (200 g $\mathrm{hl}^{-1}$ ) was applied two weeks before harvest. The control plants were sprayed with water alone.

To assess powdery mildew diffusion and damage severity, visual inspections of the central row (7 plants) of each plot were carried out, 
every week, starting from crop taking root. For each plant, 5 leaves were inspected, assigning to each one a score according to 5 levels of attack $(0=$ absence of attack; 1 = attack involving 1 $25 \%$ of the leaf surface; $2=26-50 \%$ of attack; $3=51-75 \%$ of attack; $4=76-100 \%$ of attack). The same scale was adopted to assess the disease severity symptoms on the melon fruits. One week before the harvest of each cultivar, 10 symptomatic leaves were sampled to identify the causal agent of the disease. The leaves were observed under the stereomicroscope for the possible presence of cleistothecia. At the same time, the mycelial growth on the leaves was used to make fresh preparations for light microscope observations. Molecular diagnostic methods based on Polymerase Chain Reaction (PCR) were also used to identify the aetiological agent. In the last years PCR has been used in plant pathology for diagnostic purposes (Camele et al., 2005; Duncan and Cooke, 2002) since it saves time and is more sensitive and accurate than traditional diagnostic techniques. Infected leaves were washed with sterile distilled water to remove the conidia, which were concentrated by filtering and centrifugation and then subjected to sonication. The total nucleic acids were extracted with a commercial kit (Dneasy Plant mini kit, Qiagen) according to the manufacturer's instructions. The DNA was amplified using the primer pair ITS4/ITS5 (White et al., 1990) whose targets are the internal transcribed spacer regions (ITS) of ribosomal DNA (rDNA). Sterile distilled water and DNA extracted from healthy melon leaves were used as controls. Amplification was carried out according to the following protocol: initial cycle at $94{ }^{\circ} \mathrm{C}$ for $3 \mathrm{~min}$, $55{ }^{\circ} \mathrm{C}$ for $30 \mathrm{sec}, 72{ }^{\circ} \mathrm{C}$ for $1 \mathrm{~min}$ followed by 33 cycles at $94{ }^{\circ} \mathrm{C}$ for $30 \mathrm{sec}, 55^{\circ} \mathrm{C}$ for $30 \mathrm{sec}$,
$72{ }^{\circ} \mathrm{C}$ for $1 \mathrm{~min}$ and a final cycle at $94{ }^{\circ} \mathrm{C}$ for $30 \mathrm{sec}, 55{ }^{\circ} \mathrm{C}$ for $30 \mathrm{sec}$ and $72{ }^{\circ} \mathrm{C}$ for $10 \mathrm{~min}$. The amplified products were visualized with a transilluminator after electrophoresis in $1.2 \%$ agarose gel and staining with ethidium bromide in presence of a molecular weight marker (1-kb DNA ladder, BRL Life Technologies). After further electrophoresis in $1.5 \%$ agarose gel, the same products were sampled, purified with the QIAquick Gel Extraction kit (Qiagen) and directly sequenced. The resulting sequences were compared with those available in data banks.

For both cultivars and in both years, the sampling was carried out in the last 10 days of $\mathrm{Au}$ gust when the melon peel presented the typical yellow colour. Successively, the number and weight of all mature fruits in each plot (7 plants) were recorded and they were classified as marketable or waste. Furthermore, on 5 marketable fruits, the following characters were recorded: mean weight, equatorial and polar diameter, width and length of the ovarian cavity, weight of the placenta and seeds, thickness of the pericarp, soluble solids content $\left({ }^{\circ}\right.$ Brix) of the pulp (mesocarp) with a digital refractometer, consistency with a penetrometer, and dry substance content after desiccation of pulp samples in a ventilated stove until constant weight.

All agronomic collected data were statistically analyzed by ANOVA and mean values were separated by Fisher's Least Significant Difference Test.

\section{Results}

\subsection{Climatic trend}

Figure 1 shows that the maximum temperature reached the highest values in the last 10 days of
Figure 1. Ten-day minimum and maximum temperature trends recorded during the two melon crop cycles compared to pluriannual (1991-2005) values.

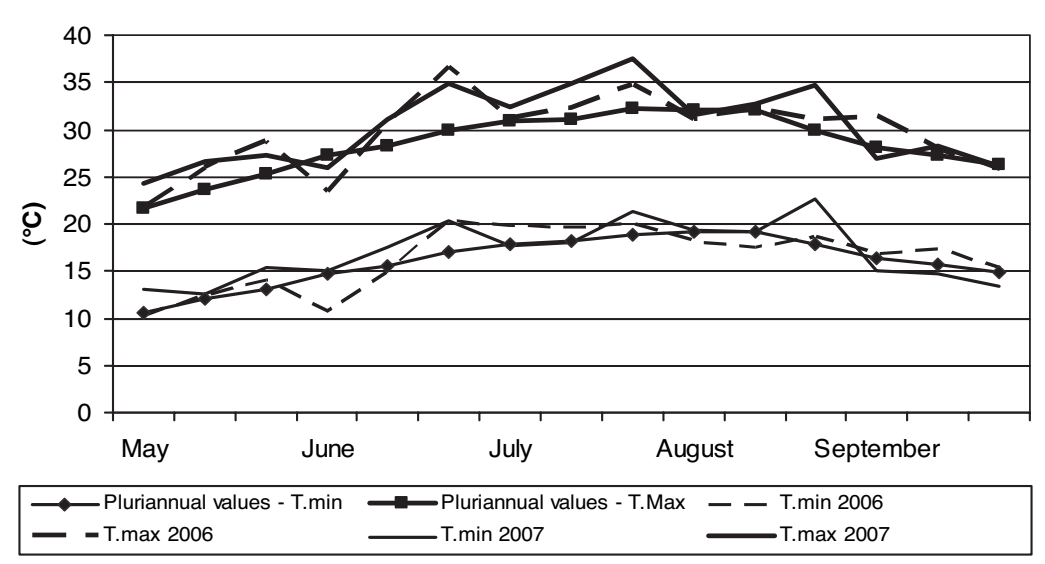


June 2006 (mean $36.7^{\circ} \mathrm{C}$ ) and 2007 (mean 34.8 ${ }^{\circ} \mathrm{C}$ ), in the second 10-day period of July 2007 (mean $34.8^{\circ} \mathrm{C}$ ) and in the third of August 2007 (mean $34.3{ }^{\circ} \mathrm{C}$ ). The highest minimum temperature values were recorded in the last 10 days of June 2006 (mean $20.4{ }^{\circ} \mathrm{C}$ ) and the last of August 2007 (mean $22.2{ }^{\circ} \mathrm{C}$ ). In both years, the mean maximum temperature was never less than $30{ }^{\circ} \mathrm{C}$ from the second 10-day period of June to the last of August, and on some days it exceeded $40{ }^{\circ} \mathrm{C}$ (June $20^{\text {th }}$ and August $20^{\text {th }} 2006$, June $21^{\text {st }}$ and $26^{\text {th }}$ and July $24^{\text {th }} 2007$ ).

Figure 2 shows the 10-day rainfall trend during the two melon crop cycles. From May to $\mathrm{Au}-$ gust 2006, rainfall was concentrated in the first 10 days of June $(15 \mathrm{~mm})$, in the first $(17.4 \mathrm{~mm})$ and second 10-day periods (24.6 mm) of July and in the first $(14.6 \mathrm{~mm})$ and second $(13.8 \mathrm{~mm})$ of August. In 2007, the rainfall was low and less frequent, occurring mainly in May $(9.8 \mathrm{~mm}$ in the first 10-day period, $15 \mathrm{~mm}$ in the second and $11.2 \mathrm{~mm}$ in the last) and June (18 $\mathrm{mm}$ in the first 10-day period). There was a complete lack of rain for all of May 2006 and from 13 June to 24 September 2007.

Figure 3 shows the trend of relative air humidity. The maximum and minimum relative humidity values were lowest in the last ten days of June $2006(71.7 \%$ and $21.4 \%)$ and the last ten days of July 2007 (60.5\% and $15.2 \%)$, while they were highest in the first ten days of May $2006(94.4 \%$ and $42.1 \%)$ and the first ten days of June 2007 (98\% and 45.9\%).

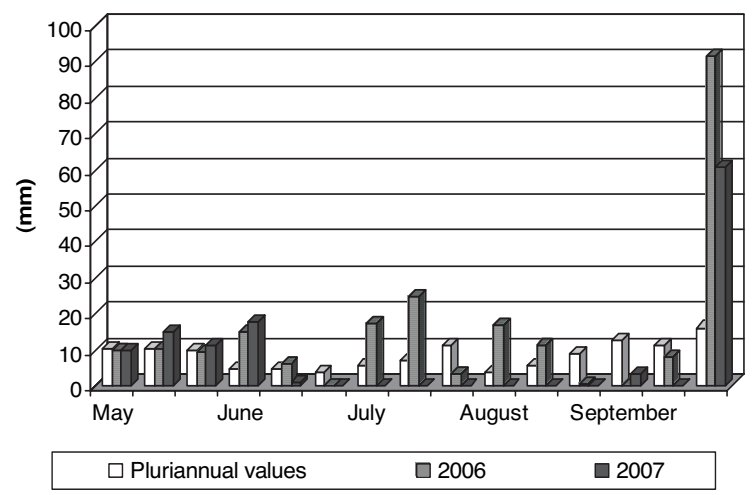

Figure 2. Ten-day rainfall trends recorded during the two melon crop cycles compared to pluriannual (1991-2005) values.

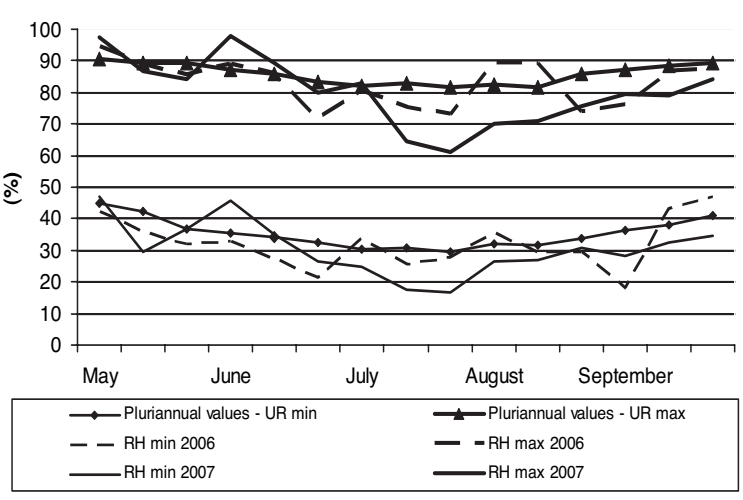

Figure 3. Ten-day minimum and maximum relative humidity trends recorded during the two melon crop cycles compared to pluriannual (1991-2005) values.

\subsection{Development of the disease}

In 2006 (Fig. 4), the first powdery mildew symptoms were observed on 18 July on some control 'Amarillo' plants. In the second survey (July $24^{\text {th }}$ ), the disease continued to be absent in 'Cocorito' but was very evident on 'Amarillo' plants with a mean attack intensity of 1.3 and with non-significant differences between the two defence strategies ('conv', 'bio') and the control. In the last three surveys, the attack was increasingly severe in 'Amarillo' up to the maximum attack degree (4) at the end of the crop cycle. The resistant genotype ('Cocorito') presented first symptoms in the third survey (July $31^{\text {st }}$ ) but they were mild and not generalized since they only involved some control plants treated with water alone; although the attack subsequently increased, the disease was never severe, as shown by the low level of attack at the end of the crop cycle (mean 1.3). No powdery mildew damage was observed on the fruits of conventionally and biologically treated plants. In all surveys and in both cultivars, the two antioidium strategies resulted in statistically similar classes of attack, which did not differ from control.

In 2007, powdery mildew was first recorded on 20 July but only on 'Amarillo'; however, the degree of attack was mild (0.2 and 0.4) and significantly lower with 'conv' than with control and 'bio'. After 6 days (July $\left.26^{\text {th }}\right)$, the attack level in this cultivar ranged between 1.3 ('conv') and 2.2 ('bio'), and the leaves of 'Cocorito' also showed mild symptoms of the disease. In the next two surveys (July $31^{\text {st }}$ and August $6^{\text {th }}$ ), the disease continued to develop more strongly on 'Amarillo', reaching a mean degree of attack of 

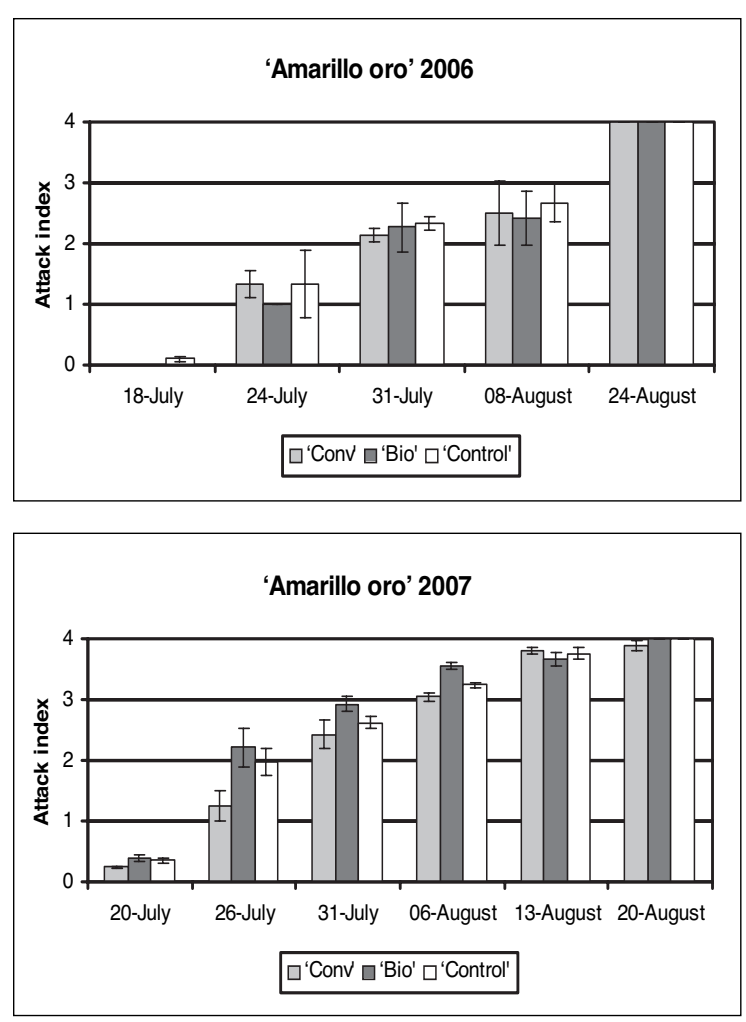

Figure 4. Distribution of powdery mildew ${ }^{(1)}$ in relation to the defence strategies used with the two melon cultivars grown in open field conditions in two years.

2.6 and 3.2 on the two dates, while the resistant cultivar was clearly less affected (degree of attack 0.6 and 0.8 respectively). In both cultivars, the conventionally treated plants showed a milder degree of attack than all the others, while those treated with Stifénia were attacked significantly more severely than the control plants. On the last two observation dates (13 and 20 August), 'Amarillo' was severely affected by powdery mildew, with the maximum degree of attack (4), and there were no significant differences between the defence strategies and the control. On the same dates, the powdery mildew attack was very limited in 'Cocorito'; 20 August $20^{\text {th }}$, i.e. the day before harvest, the degree of attack was still below 3. Moreover, in both surveys, the intensity of attack with the conventional treatment was significantly lower than control, whereas the results with the biological and control treatments were statistically similar.

\subsection{Identification of the disease aetiological agent}

Stereomicroscopy observations of the infected leaves and light microscopy observations of the
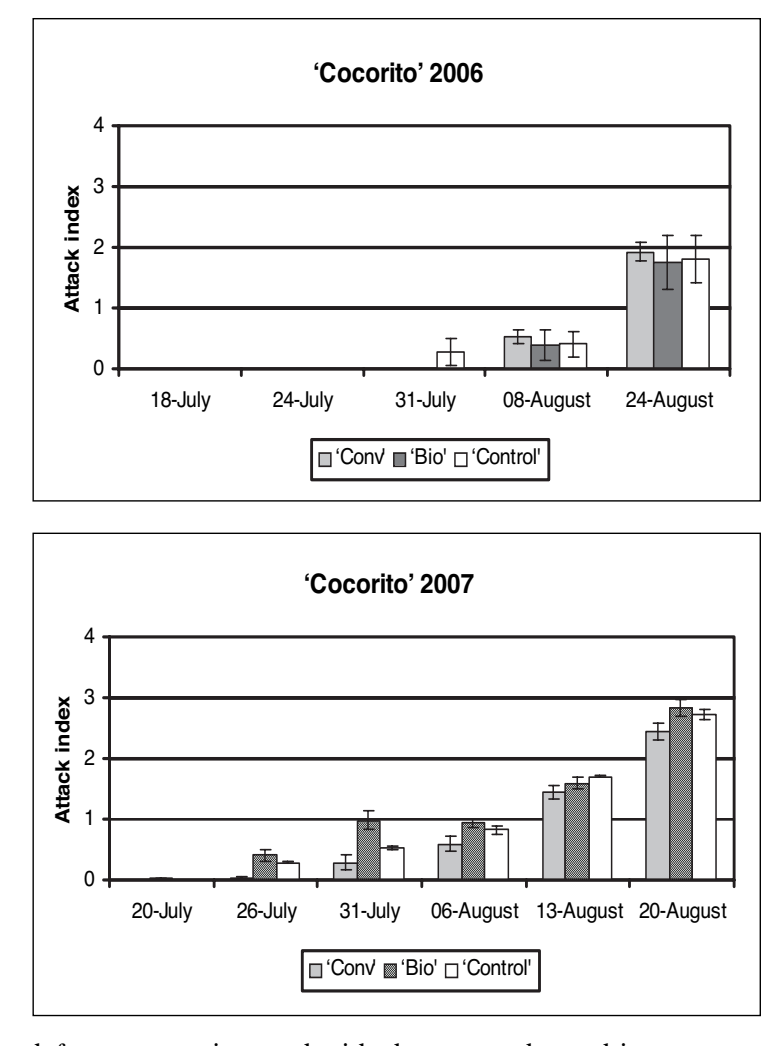

mycelial growths did not reveale the presence of cleistothecia. Instead, elliptical conidia measuring 31-40 x 20-25 $\mu \mathrm{m}$ were observed. The conidia, observed in a $3 \% \mathrm{KOH}$ solution, were lacking fibrosin bodies (Kable and Ballantyne, 1963). PCR amplification with the ITS4/ ITS5 primer pair produced visible amplicons of around $600 \mathrm{bp}$. No amplification products were found when DNA was extracted from healthy melons or when the DNA was replaced by sterile distilled water. The resulting sequences were very similar and closely related to those of $G$. cichoracearum when compared with data bank sequences using BLAST software (Altschul et al., 1997). Microscopic observations and, above all, gene sequencing of the ITS region indicated G. cichoracearum as the species responsible for the powdery mildew on the tested melon plants.

\subsection{Yield response}

Melon productivity in the two-year research was conditioned by the factor Year (table 1), which significantly affected the main morpho-produc- 
Table 1. Effect of anti-oidium control strategies on morpho-productive and qualitative characters in two inodorus melon cultivars grown in open field conditions in two years.

\begin{tabular}{|c|c|c|c|c|c|c|c|c|c|c|c|}
\hline \multirow{4}{*}{ Treatments } & \multicolumn{11}{|c|}{ MORPHO-PRODUCTIVE AND QUALITATIVE CHARACTERS } \\
\hline & \multicolumn{4}{|c|}{ Yield } & \multicolumn{7}{|c|}{ Fruits } \\
\hline & \multicolumn{2}{|c|}{ marketable } & \multicolumn{2}{|c|}{ total } & \multirow{2}{*}{$\begin{array}{c}\text { mean } \\
\text { weight }\end{array}$} & \multicolumn{2}{|c|}{ diameter } & \multirow{2}{*}{$\begin{array}{c}\text { pericarp } \\
\text { thick- } \\
\text { ness } \\
(\mathrm{mm})\end{array}$} & \multirow{2}{*}{$\begin{array}{c}\text { pulp } \\
\text { dry } \\
\text { matter } \\
(\%)\end{array}$} & \multirow[b]{2}{*}{$\begin{array}{c}\text { soluble } \\
\text { solids } \\
\left({ }^{\circ} \text { Brix }\right)\end{array}$} & \multirow[b]{2}{*}{$\begin{array}{c}\text { consi- } \\
\text { stency } \\
\left(\mathrm{kg} \mathrm{cm}^{-2}\right)\end{array}$} \\
\hline & $\begin{array}{c}\text { per } \\
\text { plant } \\
\text { (no.) }\end{array}$ & $\left(\mathrm{t} \mathrm{ha} \mathrm{h}^{-1}\right)$ & $\begin{array}{c}\text { per } \\
\text { plant } \\
\text { (no.) }\end{array}$ & $\left(\mathrm{t} \mathrm{ha} \mathrm{h}^{-1}\right)$ & & $\begin{array}{l}\text { polar } \\
(\mathrm{cm})\end{array}$ & $\begin{array}{l}\text { equat. } \\
(\mathrm{cm})\end{array}$ & & & & \\
\hline \multicolumn{12}{|l|}{ Years $(A)$} \\
\hline 2006 & 2.4 & 35.2 & 2.6 & 36.8 & 2942 & 15.4 & 24.4 & 5.8 & 13.2 & 14.6 & 3.4 \\
\hline 2007 & 3.3 & 48.5 & 3.4 & 49.1 & 2988 & 16.3 & 25.9 & 10.1 & 11.3 & 13.6 & 4.7 \\
\hline Significant ${ }^{(1)}$ & $* *$ & $* *$ & $* *$ & $* *$ & n.s. & $* *$ & $* *$ & $* *$ & $* *$ & $* *$ & $*$ \\
\hline \multicolumn{12}{|c|}{ Anti-oidium strategies_(S) } \\
\hline 'Conv' & 3.0 & 44.1 & 3.1 & 45.4 & 2953 & 15.8 & 25.3 & 8.2 & 12.6 & 14.8 & 4.3 \\
\hline 'Bio' & 2.7 & 40.3 & 3.1 & 41.6 & 3006 & 15.8 & 25.0 & 7.7 & 12.0 & 13.7 & 4.2 \\
\hline 'Control' & 2.8 & 41.2 & 3.0 & 42.0 & 2936 & 16.0 & 25.1 & 8.0 & 12.1 & 13.8 & 4.5 \\
\hline$L S D 0.05 P$ & 0.14 & 2.1 & n.s. & 1.0 & n.s. & n.s. & n.s. & n.s. & 0.4 & 0.8 & n.s. \\
\hline LSD $0.01 P$ & - & 2.7 & & 1.5 & & & & & - & - & \\
\hline \multicolumn{12}{|l|}{ Cultivars $(C v)$} \\
\hline 'Amarillo oro' & 2.2 & 33.3 & 2.5 & 34.6 & 2994 & 15.9 & 26.5 & 7.6 & 11.6 & 13.4 & 3.5 \\
\hline 'Cocorito' & 3.5 & 50.5 & 3.6 & 51.3 & 2936 & 15.8 & 23.8 & 8.3 & 12.9 & 14.8 & 5.2 \\
\hline Significant ${ }^{(1)}$ & $* *$ & $* *$ & $* *$ & $* *$ & n.s. & n.s. & $* *$ & $*$ & $* *$ & $* *$ & $* *$ \\
\hline \multicolumn{12}{|l|}{ Interactions } \\
\hline$A \times S$ & n.s. & $*$ & n.s. & $* *$ & $n . s$ & n.s. & n.s. & n.s. & $*$ & $*$ & n.s. \\
\hline$A \times C v$ & $* *$ & $* *$ & $* *$ & $* *$ & n.s. & n.s. & n.s. & n.s. & n.s. & n.s. & n.s. \\
\hline$S \times C v$ & n.s. & n.s. & n.s. & n.s. & n.s. & n.s. & n.s. & n.s. & n.s. & n.s. & n.s. \\
\hline$A \times S \times C v$ & n.s. & n.s. & n.s. & $* *$ & n.s. & n.s. & n.s. & n.s. & n.s. & n.s. & n.s. \\
\hline
\end{tabular}

$(1) *=$ Significant at $\mathrm{P} \leq 0.05 ; * *=$ Significant at $\mathrm{P} \leq 0.01 ;$ n.s. $=$ Not significant difference.

tive and qualitative characters. For example, the marketable yield increased from $35.2 \mathrm{t} \mathrm{ha}^{-1}$ in 2006 to $48.5 \mathrm{t} \mathrm{ha}^{-1}$ in 2007 , while the ${ }^{\circ}$ Brix decreased from 14.6 to 13.6 ; the mean weight of the melons remained virtually unchanged at 2.9 $\mathrm{kg}$. The anti-oidium treatments also had a significant effect on the productive and qualitative characters (Tab. 1). The conventional treatment provided a higher marketable yield in terms of both weight (44.1 t ha-1 vs. $40.3 \mathrm{t} \mathrm{ha}^{-1}$ for the biological treatment) and quality ( ${ }^{\circ}$ Brix $14.8 v s$. 13.7). The higher yields with the conventional treatment were due to the higher number of fruits per plant rather than a mean weight difference (not significant). In the first year, the repeated Stifénia applications ('bio') resulted in a decrease of the marketable (Fig. 5) and total yield (data not shown) also with respect to control plants; in the same year the soluble solids content (Fig. 5) and the dry matter (data not shown) of fruits were significantly lower in Stifénia treated plots.
The 'Cocorito' hybrid was significantly more productive $\left(+17.2 \mathrm{t} \mathrm{ha}^{-1}\right)$ than the 'Amarillo' cultivar and produced higher-quality fruits, as shown by the higher sugar content, dry substance (\%) and consistency (Tab. 1). The higher productivity of 'Cocorito' was more evident in the second year, as shown by the significant "Year x Cultivar" interaction (Tab. 1).

\section{Discussion and conclusions}

The results of this research indicate that Stifénia is not efficacious against powdery mildew of melon in the conditions adopted in the trials. The conventional products were able to contain the disease severity but the level of protection was barely sufficient. This is likely due to the appearance of paghoten strains insensitive to the action of the synthetic anti-oidium products, which thus lose their efficacy (Brunelli et al., 1996; La Torre et al., 2001; Santomauro et al., 


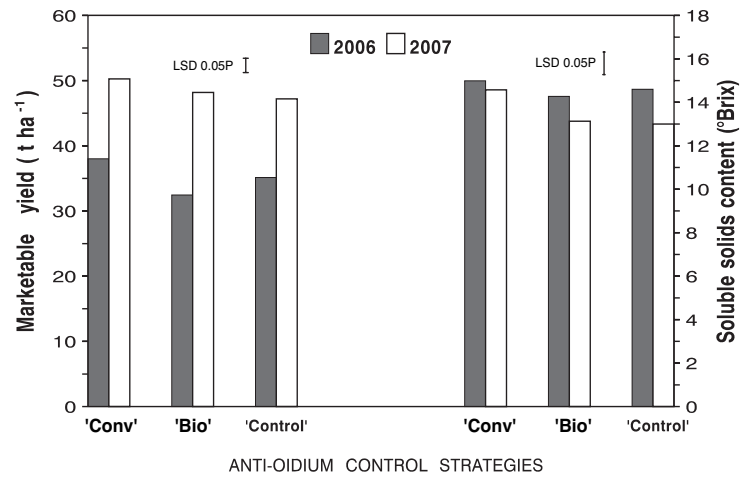

Figure 5. Interactive effect of "Years x Anti-oidium strategies" on marketable yield and soluble solids content of melon fruits.

2003). To prevent this, defence strategies that minimize the risk of development of resistant strains should be adopted. It is advisable to limit number of treatments with the same active principle and, above all, to use products with different action mechanisms.

Satisfactory results were obtained with the 'Cocorito' hybrid, which was able to limit powdery mildew attacks. In fact, this cultivar was only mildly infected by the pathogen and the attack occurred much later than in 'Amarillo', which does not have genes of resistance to powdery mildew. 'Cocorito' also presented higher productivity and quality of the fruits.

The decreased production observed with the use of Stifénia ('bio'), evident in conditions of severe ('Amarillo') and 'mild' ('Cocorito') powdery mildew attack, needs to be explained.

The identification of new defence strategies against powdery mildew, perhaps the most important disease of melon and frequent cause of decreased production and qualitative fruit decline, is essential to promote melon growing in southern Italy, where there are several areas with optimal conditions for this crop.

The general primers PN23/PN34 are well established for the molecular identification of the aetiological agents of powdery mildew (Bardin et al., 1999). Species-specific primers called S1/S2, G1/G2 and L1/L2, based on sequence variations of the ITS region and specific for $P$. xanthii, G. cichoracearum and L. taurica were recently designed (Chen et al., 2008); they are able to amplify a portion of rDNA of these fungi of, respectively, 454, 391 and 374 bp. Devel- opment of these primers has allowed the identification, also in mixed infections, of $P$. xanthii and $G$. cichoracearum by means of multiplex PCR (Chen et al., 2008).

The possibility of rapid, sensitive and, above all, early identification of the aetiological agent(s) of powdery mildew of melon will also allow the development of more effective forms of control of these pathogens, which can differ in pathogenicity toward cucurbits (Epinat et al., 1993).

\section{Acknowledgements}

This work was carried out within the research project PROM (Progetto di Ricerca per potenziare la competitività di Orticole in aree Meridionali - Contributo finanziario MIPAF con fondi C.I.P.E., Delibera 17/2003). Scientific coordinator: Dr. Agostino Falavigna.

We thank Paolo Putignano and Cosimo Danzi for their valuable help in conducting experimental trials and agronomic data collecting.

\section{References}

Altschul S.F., Madden T.L., Schaffer A.A., Zhang J., Zhang Z., Miller W., Lipman D.J. 1997. Gapped BLAST and PSIBLAST: a new generation of protein database search programs. Nucleic Acids Research, 25:3389-3402.

Bardin M., Carlier J., Nicot P.C. 1999. Genetic differentiation in the French population of Erysiphe cichoracearum, a causal agent of powdery mildew of cucurbits. Plant Pathology, 48:531-540.

Braun U. 1995. The powdery mildews (Erysiphales) of Europe. Jena, Germany: G. Fischer Verlag: 337 pp.

Brunelli A., Flori P., Collina M., Coatti M., Cobelli L. 1996. Attività di prodotti vegetali e minerali contro l'oidio delle cucurbitacee (Sphaerotheca fuliginea). Atti Giornate Fitopatologiche, 2:465-472.

Brunelli A. 2007. Oidio delle cucurbitacee, quali strategie di difesa. L'informatore Agrario, 21:57-59.

Camele I., Marcone C., Cristinzio G. 2005. Detection and identification of Phytophthora species in southern Italy by RFLP and sequence analysis of PCR-amplified nuclear ribosomal DNA. European Journal of Plant Pathology, 113:1-14.

Chen R.-S., Chu C., Cheng C.-W., Chen W.-Y., Tsay J.G. 2008. Differentiation of two powdery mildews of sunflower (Helianthus annuus) by a PCR-mediated method based on ITS sequences. European Journal of Plant Pathology, 121:1-8.

Clergue T., Martinez C. 2006. Lutte contre l'oidium avec Stifenia stimulateur de defenses naturelles. Phytoma: La defense des vegetaux, 591:40-41. 
Duncan J., Cooke D. 2002. Identifying, diagnosing and detecting Phytophthora by molecular methods. The Mycologist, 16:59-66.

Epinat, C., Pitrat M., Bertrand F. 1993. Genetic analysis of resistance of 5 melon lines to powdery mildews. Euphytica, 65:135-144.

Fernandez-Ortuno D., Perez-Garcia A., Lopez-Ruiz F., Romero D., de Vicente A., Tores J.A. 2006. Occurrence and distribution of resistance to QoI fungicides in populations of Podosphaera fusca in south central Spain. European Journal of Plant Pathology, 115:215-222.

Garibaldi A., Bertetti D., Frati S., Gullino M.L. 2008. First report of powdery mildew caused by Golovinomyces cichoracearum on orange coneflower (Rudbeckia fulgida) in Italy. Plant Disease, 92(6):975.

http://www.istat.it/agricoltura/datiagri/coltivazioni/anno2007/ital2007.htm

Incalcaterra G., Vetrano F. 2007. La coltivazione del melone e dello zucchino in pien'aria in Italia. Atti Workshop “Orticoltura in pien'aria in Italia: quali prospettive per il comparto?", 11 maggio 2007. Sassari. Vito Radio Ed.: 73-96.

Kable P.F., Ballantyne B.J. 1963. Observation on cucurbit powdery mildew in the Ithaca district. Plant Disease Report, 47:482.

McGrath M.T., Shishkoff N. 2003. Resistance to strobilurin fungicides in Podosphaera xanthii associated with reduced control of cucurbit powdery mildew in a research field. Phytopathology, 93:S59.

La Torre A., Pompi G., Cozzolino G., Severoni A. 2001. Lotta all'oidio dello zucchino con prodotti naturali. L'informatore agrario, 57(17):77-81.

Santomauro A., Casulli F., Tauro G., Gatto M.A., Dongiovanni C., Giampaolo C., Faretra F. 2003. Protezione antioidica delle cucurbitacee con prodotti naturali. Informatore Fitopatologico, 53(7-8):36-42.

White T.J., Bruns T., Lee S., Taylor J.W. 1990. Amplification and direct sequencing of fungal ribosomal RNA genes for phylogenetics. In: Innis M.A., Gelfand D.H., Sninsky J.J. and White T.J. (eds.): PCR Protocols: A Guide to Methods and Applications. Academic Press, New York: 315-322. 